\title{
The Development of Science Education During the Ability-Driven Phase in Singapore, 1997-2011
}

\author{
Vanessa Vinodhen \\ University of Western Australia, \\ 35 Stirling Hwy, Crawley WA, 6oog, Australia \\ vanessa.vinodhen@gmail.com \\ Received: 4 February 2020 | Revised: 4 May 2020, 26 May 2020 | \\ Accepted: 1 July 2020
}

\begin{abstract}
This paper presents historical analysis of the development of science education in Singapore from 1997 to 2011 with the aim of understanding the impact of education initiatives introduced during this period known as the ability-driven phase in Singapore. To provide context for the research, the author first describes the state of governance and education in Singapore during this period and then provides an introduction to the Thinking Schools, Learning Nation vision, and two main educational initiatives: the Teach Less, Learn More initiative and the Information Technology Masterplan. Next the impact of these initiatives on science education is explored and the impact on science culture and science education in Singapore is discussed. The author concludes with a discussion about value of historical analysis examining the impact of policy on educational practice and a discussion about the implications of this research for science and science education in Singapore in the future.
\end{abstract}

\section{Keywords}

ability-driven phase - historical analysis - Singapore education system

\section{Introduction}

The Singapore education system is widely considered to be one of the best in the world, as students have routinely performed at the highest levels on 
international comparative assessments for math, science, and reading. Singapore has overtaken the wealthiest countries in Europe, North America, and Asia to become the number one in education (Coughlan, 2016). Science educators interested in improving student performance in science are interested to know more about Singapore's curriculum reform in science education. One of the major contributors to the consistently good performance in science education are the educational visions put in place in the late 199os (Tan et al., 2014).

The period from 1997-2011 was a particularly transformative time for science education, known as the ability-driven phase. During this time, the Singapore government focused relentlessly on education as a way of developing its economy and raising living standards (Tan et al., 2014). The government invested not only in a quality teaching force (Tan, 2018), but also in a versatile education system with strategic educational policies to support economic growth (Tan et al., 2016). At the end of the ability-driven phase, there were obvious improvements in the quality of science education (Tan, Lim, \& Poon, 2014). For example, the Trends in International Mathematics and Science Study (TIMSS) in 2011 reported Singapore was among the top performing countries in science. Students showed an increase in ability in the reasoning domains of the test from 2007 to 2011. Singapore also had the highest proportion of students attaining the highest Advanced TIMSs Benchmark for science in 2011 and 2015 (Mullis et al., 2016). In the same time period, on the 2009 Programme for International Student Assessment (PISA), conducted by the Organisation for Economic Co-operation and Development (OECD), Singapore scored an average of 542 points in science, which is significantly higher than the average of 500 for the other OECD countries (Teh, 2014). In 2018 it was reported that $91 \%$ of Singapore students attained Level 2 or higher in science, which was significantly more than the average of $78 \%$ across OECD countries (OECD, 2019).

It is clear that the effects of these visions for improvements implemented during the ability-driven phase continue to manifest in the efforts and programs in schools today. Therefore, there is significant value in understanding the impact of one of these visions and its initiatives on science education in Singapore. This article hopes to shed light on the policies and initiatives that have helped Singapore become a recognized nation with its sustained achievement in international science studies.

\section{2 \\ Research Aims and Questions}

In proposing a historical analysis of the development of science education in Singapore during the ability-driven phase, this paper will explore the following questions: 
1. What are some significant education initiatives introduced during the ability-driven phase of Singapore's development of science education?

2. How did these policies have an impact on science education in Singapore during the period of 1997 to 2011 ?

Through a historical analysis of the initiatives introduced during the abilitydriven phase, this study explores the impacts of these initiatives on the education system in Singapore with a special focus on understanding how these policies supported the development of science education to progress so rapidly in this period. In answering these questions, this paper describes recent developments of the education system pertaining to the teaching of science in secondary schools in Singapore from 1997 to recent times. By drawing from the lessons of history, this paper hopes to contribute to a more global debate on the changing landscape of science education. The sections that follow provide a brief introduction to Singapore and a description of the ability-driven phase policies that sought to improve the quality of science education (Tan et al., 2014).

\section{3}

\section{Singapore and the Ability-Driven Phase Policies}

Singapore is a small island with a relatively large population. One advantage Singapore has over its neighbors is its strategic location at the southern tip of the Malay Peninsula, which has made Singapore a viable trading port. However, with few natural resources, there is a heavy reliance on human capital and ensuring that its people are skilled enough to create a robust workforce that will run and sustain its economy (Tan, Lim, \& Poon, 2014). Therefore, the education sector became a focal point in ensuring the economic success of the nation. During the late 199os, as globalization and technological advancements hastened the progress of other countries, Singapore struggled to remain competitive in an ever-changing economic landscape (Gopinathan, 2013). The emergence of a knowledge-based economy has shifted the emphasis and the position of education and knowledge in society (Lee et al., 2008). There was a greater reliance on the intellectual capabilities of an individual and their ability to apply the knowledge acquired. The pressure on the education system to produce such high-functioning individuals to drive this knowledge-based economy was immense. This shift in the education landscape called for a replacement of traditional teaching methods with more progressive pedagogical approaches such as collaborative learning and differentiated teaching (Tan, Chow, \& Goh, 2008).

For Singapore to continue to survive and thrive in a volatile, uncertain, complex, and ambiguous world, it was imperative that much investment was given to the nurturing and development of the workforce through a flexible 
and versatile education system. Lee et al. (2008) further explain that due to the emergence of knowledge-based economies, the ability to accumulate knowledge is no longer sufficient. Students need to be adept in processing data that is made available through the many channels of information technology into usable information. Many countries have recognized the need to reshape and realign their educational policies in order to equip their citizens with the necessary knowledge and skills (Power, 2007). Singapore recognized this need for educational change and adapted with the introduction of the vision of Thinking Schools, Learning Nation (TSLN) in 1997. This vision was aimed specifically at dealing with the knowledge-based economy. Initiatives under the TSLN movement had a significant impact on the direction of science curriculum, pedagogy, and assessment during this period (Tan et al., 2014).

As the economic landscape evolved into one more focused on manufacturing, the emphasis on the teaching of science in Singapore secondary schools increased. The science curriculum was reduced to free up curricular time for thinking skills and the use of information and communication technology (ICT) tools. It was also adjusted to reflect new developments in science and technology (Tan et al., 2014), and there was an emphasis on life sciences. Two initiatives that had an impact on the direction of science education in Singapore in particular were the Teach Less, Learn More (TLLM) initiative introduced in 2005 and the Information and Technology (Iт) Masterplan introduced during the period of 1997 to 2002. The TLLM initiative sharpened the focus on the quality of teacher-student interaction that would nurture inquiring minds and independent learners (Tan et al., 2014). The Iт Masterplan allowed the use of ICT to be innovatively harnessed as a tool for enhancing teaching and learning (Tan et al., 2016). All this was in alignment to the TSLN vision of promoting creativity, lateral thinking, and problem-solving skills (Boo, 2003). In the sections that follow, the method adopted for this research is explained and a description of the state of governance and education in Singapore during the 199os is provided to give more context for this research.

Method

In this research, the author used a process of historical triangulation. Historical research is unique as it focuses primarily on the past where there is no manipulation or control of variables like there is in experimental research. Historical research is the systematic collection and evaluation of data to describe, explain, and thereby understand events that occurred in the past (Fraenkel \& Wallen, 2010). This research focused primarily on the study of historical documents to 
address the research questions. Triangulation of the data was necessary to ensure validity of the results. This process involves gathering multiple data from a variety of sources independently to offer insight into the same research question (Lange, 2013). This allows the researcher to ascertain accurate conclusions (Fraenkel \& Wallen, 2010). In this research, a variety of sources of historical documents were used and the data obtained from the historical documents were triangulated. The following steps, which were a combination of Punch's (2013) and Fraenkel and Wallen's (2010) insights into historical research and triangulation of data, were used:

1. Identifying the purpose, cause, or problem that determines the research content: In this research it is the development of science education in Singapore from 1997 to 2011.

2. Location of relevant sources, which is where triangulation was involved. There were numerous primary and secondary sources as well as speeches, books, seminar reports, and journals. The data were compared to allow verification of events and outcomes.

3. Summarizing the information from the sources, which involves determining the relevancy of the data.

4. Evaluating the sources. A critical attitude was adopted when evaluating the sources and the data. For historical data, it is sometimes difficult to ascertain whether the author was present during the events stated.

5. Data analysis. Data were analyzed using the general qualitative data analysis method described by Miles and Huberman (2014). The Miles and Huberman method describes a concurrent three-step process: data reduction, data display, and drawing and verifying conclusions.

The sources were of three kinds: archive materials, such as printed copies of newspaper reports and government speeches from 1997 onwards; publications on the history of Singapore before 1997; and contemporary materials such as publications about Singapore's education system found in the National Library of Singapore. By following the steps listed above, an insight into how Singapore achieved success in curriculum reform in science education was achieved.

\section{State of Governance and Education during the 199os}

Singapore attained independence from colonial reign in 1965 led by the People's Action Party (PAP), a local democratic political party led by former Prime Minister Lee Kuan Yew. With keen competition, hastened along by globalization and technological advancements, Singapore chartered new economic directions (Tan, Lim, \& Poon, 2014). 
Singapore was in an efficiency-driven phase before 1997 in which the focus was on an economy with a labor-intensive workforce with lower skills. The efficiency-driven phase focused on producing skilled workers for the economy, whereas the ability-driven phase focused on identifying and developing the talents and abilities of students. Regional competition in the traditional manufacturing and services sector intensified during the 1970s, and Singapore recognized the need to broaden and diversify its economic base. There was a need to transform into a knowledge-based economy (Tan, Lim, \& Phua, 2017) from a labor-intensive economy. Therefore, Singapore began exploring the research and development sector in 1985 (Tan, Lim, \& Phua, 2017). Research and development became a cornerstone in developing a knowledge-based economy. Therefore the efficiency-driven phase did see the initial development of a more rigorous science education in Singapore. The focus on research and development in the area of science signified an important shift in the relevance of the teaching of science. There was a need to ensure the development of competent science and biology teachers and a structured curriculum in secondary schools to support the teaching and learning of science and biology. Therefore, much time during the efficiency-driven phase was spent on the development of teacher training. The ability-driven phase marked a more strategic move into a higher-end knowledge-based economy with specific initiatives targeted at the improvement of science education.

The Singapore government in 1997 ascertained that it was necessary to shift towards a knowledge-based economy in which skills and knowledge were required. This initiative aimed to equip and prepare students to meet the challenges in a knowledge economy by taking into consideration their individual abilities and talents, rather than the sole reliance on examination grades (Tan, Chow, \& Goh, 2008). The initiative also represented a paradigm shift from the efficiency-driven phase (1979-1997). Former Senior Minister of State for Education, Peter Chen, emphasized the need for an education system in a knowledge economy to provide a balanced and well-rounded education that would develop every individual in the most appropriate manner such that their full potential can be realized (Tan, Chow \& Goh, 2008).

Singapore maintains a highly centralized education system (Tan, Gopinathan, \& Ho, 2001) in which the Ministry of Education determines the curriculum and the syllabus. The education structure in Singapore follows a three-part system: six years of primary school, four years of secondary school, and two or three years of pre-university education. Students are therefore provided with at least 10 years of basic and compulsory education. All Singapore citizens at the age of seven will begin their education with a compulsory six-year education in primary school. This is followed by a four- or five-year secondary course. 
Following the secondary school course, there are a variety of pathways as determined by the students' choices and abilities (Ministry of Education, n.d).

Singapore during the ability-driven phase was charting new economic directions supported by the transformation in education. As mentioned, one of the key visions that played an important role in the development of science education is the TSLN vision. This vision, together with the initiatives that followed, will be described next.

The author has analyzed in some depth the state of governance and education in Singapore during the 199os that set the context for the development of science education during the ability-driven phase. It was clear that education was to play a key role in the economic transformations that were envisioned for Singapore during the ability-driven phase. The transformation began with the introduction of the TSLN vision in 1997. This vision redefined science education in Singapore. This next section is in response to the first research question about the significant education initiatives introduced during the ability-driven phase of Singapore's development of science education.

In 1997, the then Prime Minister, Goh Chok Tong, spoke about the need for schools to prepare students to meet the challenges of a rapidly changing world in the 21st century. He summed up this vision for schools as TSLN. This vision involved giving the opportunity to students and teachers to challenge assumptions and explore better ways to do things through participation, creativity, and innovation. The curriculum was revamped to allow more time for the introduction of thinking skills and the use of ICT (Gopinathan \& Chong, 2008).

With this vision, schools were expected to move away from an education delivery that emphasized academic results to one that would be balanced and holistic (Tan et al., 2014). With increased autonomy given to schools to manage education delivery, there was a need for schools themselves to take ownership of the drive for education improvement and growth. After the unveiling of the vision, many important educational initiatives were introduced. These initiatives, which have had a direct impact on science teachers' classroom practices, the TLLM initiative and the IT Masterplan are described below. The Prime Minister of Singapore, Lee Hsien Loong, introduced the TLLM initiative in 2004 during his National Day speech to the nation. The initiative was intended to promote more engaged learning, high-quality teaching, and innovative and effective instructional approaches. As described by the then education minister, Tharman Shanmugaratnam, the intention of the initiative was to encourage 
teachers to engage students in a more innovative and effective manner rather than to teach for tests and examinations (Tan, 2012). Through this initiative, teachers were strongly encouraged to adopt pedagogical approaches that were progressive and innovative. Teachers were also encouraged to refrain from the drill and practice approach in which emphasis is placed on grades. It was also envisioned that the TLLM initiative would produce innovative and thinking students who would support the growth of the knowledge-based economy.

The Iт Masterplan involved improving students' information literacy, which had become an important aspect of students' learning. It refers to the ability of students to analyze and use information provided to them (Mokhtar, 2005). Resource-based learning in which printed materials are used for the purpose of teaching and learning has been in use in schools for a long time. Singapore government schools are heavily reliant on resource-based learning; therefore, there is a strong dependence on resources in the area of textbooks, workbooks, and practical books. In 2009, the National Institute of Education (NIE) released A Teacher Education Model for the 21st Century. NIE is the only teacher training institute in Singapore, and all teachers teaching in government schools in Singapore have to attend a mandatory pre-service course to be certified to teach (Tan, 2018). The NIE proposed skill sets for students, comprising information literacy, media literacy, and Iст literacy. The model highlighted a concerted effort to move away from the dependence on books and instead onto the development of media and ICT literacy. The shift towards implementation of ICT in the classroom with the introduction of the IT Masterplan in 1997 encouraged innovations in the use of ІСт that centered on learning of 21st century competencies, self-directed learning, and collaborative learning (Tan et al., 2016). ICT-related courses became a prerequisite for pre-service teachers as well as in-service teachers (Tan, 2018).

\section{Impact of the Educational Initiatives on Science Education}

The previous section highlighted the initiatives introduced during the abilitydriven phase and provided a brief description of its desired outcome. In this section, the impact the initiatives under the TSLN movement had on the direction of science education in Singapore is further explored. Although the efficiency-driven phase did see the beginnings of a comprehensive science education, the initiatives during the ability-driven phase were strategic in creating a more sustainable and successful science education in Singapore. This section answers the second research question of how the introduced policies 
had an impact on science education in Singapore during the period of 1997 to 2011, which will be explored in four areas, as listed below.

1. Impact on science education: Life sciences and inquiry approach

2. Impact on training of science teachers at NIE

3. Impact on teaching and learning support provided

4. Impact on assessment

\subsection{Impact on Science Education}

The science curriculum was reduced to free up curricular time for thinking skills and the use of ICT (Tan et al., 2014). It was also adjusted to reflect new developments in science and technology, with an emphasis on life sciences. Singapore identified life sciences as a new engine for economic growth (Tan, 2015), and this was manifested in the emphasis on life sciences in the secondary school curriculum and at universities as part of the nation's strategic move towards a knowledge-based economy. Life sciences or biological sciences comprise the branches of science that involve the scientific study of life and organisms, such as microorganisms, plants, and animals, including human beings, and including aspects of molecular biology. This move towards an emphasis on life sciences was in alignment to Singapore's move towards ensuring that students become prepared for the advancements in science technology of the 21st century (Tan, 2016). In 2000, developments in life sciences focused on the molecular level, where there was a greater emphasis on molecular biology in the secondary school biology curriculum (Tan, 2015). Schools were also provided with more funding to support this review of curriculum.

In addition, there was a shift in the teaching and learning of science to an inquiry-based approach. The objective was to create a nation of thinking and committed citizens who are able to face the challenges of the future (Tan, Lim, \& Poon, 2014) as well as to develop students as active learners rather than passive recipients of knowledge. The science curriculum in Singapore secondary schools started focusing on the inquiry approach in 2008 (Tan, 2015). The 2008 revamp in curriculum gave explicit emphasis to inquiry in the teaching of science. Science as inquiry suggests that science teaching is no longer only about students' acquisition of content knowledge but also about skills, strategies, and habits of mind associated with decision making and problem solving (Tan, Talaue, \& Kim, 2014). The "Five E" model developed by the Biological Sciences Curriculum Study is used to support the inquiry approach through lesson planning and implementation (Bybee \& Fuchs, 2006). This model includes five stages in the teaching and learning process: engage, explore, explain, elaborate, and evaluate. 


\subsection{Impact on the Training of Science Teachers (NIE)}

An important difference between the traditional classroom and an inquirybased classroom is the role played by the students (Tan \& Tan, 2014). In traditional classrooms, students play a passive role as recipients of knowledge. An inquiry-based classroom aims to develop students as active learners who take ownership of their learning. Such autonomy in their learning may allow them to set the direction of how the lesson progresses. In order for the teacher to orchestrate inquiry-based learning, they must know where their students are located in the learning journey (Tan, 2015). This requires the teacher to elicit information actively and continuously about students' learning (Black \& Wiliam, 1998). Therefore, the National Sciences and Science Education Academic Group at the National Institute of Education has developed five customized courses on the inquiry approach since 2007 (Tan et al., 2014). The objective was to ensure professional development for teachers that would help them understand the inquiry approach. These professional development approaches were also important in ensuring accurate communication of the intent of the new science curriculum.

As mentioned earlier, NIE also proposed skill sets for students, comprising information literacy, media literacy, and ICт literacy that provided teachers with a structured approach to introducing ICT into the classroom. Then Minister for Education Tharman Shanmugaratnam, in his annual address to principals, teacher educators, and education policymakers at the Ministry of Education 2005 work plan seminar, reiterated this: "We are progressively shifting the balance in education, from learning content to developing a habit of inquiry. To engage them and prepare them for life than to prepare for tests and examinations" (Shanmugaratnam, 2005).

\subsection{Impact on Teaching and Learning Support Provided}

During this phase, funding was provided to schools to support the teaching and learning of life sciences. Primary schools received funding for an additional science room. Two guidebooks providing suggested life sciences activities were published to ease the teachers into the teaching of life sciences (Teo, 2003). The Curriculum Planning and Development Division of the Ministry of Education (Teo, 2003) also published a book on biosafety guidelines to assist the teachers in the practical activities associated with life sciences. However, the actual implementation of the curriculum on life sciences was still met with hesitation and apprehension on the part of the teachers, mainly due to their perceived inability to manage the topic. In spite of this, the manner in which the science community attempted to assist in easing the difficulties of the 
teachers reflected the support provided for science education in Singapore. As additional support for the life sciences approach, the DNA Centre was set up at the National Institute of Education in 2003 to provide teachers and students with hands-on experience of investigations and practicals in the area of life sciences (Teo, 2003). A similar DNA Learning Lab was set up at the Singapore Science Centre in 2003 to make the knowledge of life sciences accessible.

Programs to enhance the landscape of life sciences were organized by the Agency for Science, Technology, and Research (A*STAR). Students were encouraged to pursue a career in life sciences through the introduction of science laboratory attachments and interaction sessions with research scientists. Students were encouraged to participate in overseas competitions such as the International Science and Engineering Fair and the Young Physicists' Tournaments. Singapore students received recognition and awards from these international competitions and that motivated more local competitions as well.

As part of the IT Masterplan, secondary schools were supported with the addition of data loggers in the science laboratories (Tan, Hedberg, Koh, \& Seah, 2006). Data loggers are machines that obtain physical data such as temperature and $\mathrm{pH}$ of specific environments. They were meant to support the inquiry approach and transform the pedagogy in teaching science during this time. However, the provision of additional support does not necessarily transform pedagogy immediately (Tan, Lim, \& Poon, 2014). A study conducted by Tan, Hedberg, Koh, and Seah (2006) reported that more than $80 \%$ of the 593 secondary school teachers surveyed used the data loggers for more teachercentered activities and demonstrations. This was in opposition to the objective the equipment was provided for. Changes in pedagogy often require time for teacher learning and are usually not accomplished immediately (Richardson \& Placier, 2001).

\subsection{Impact on Assessments}

According to Tan and Tan (2014), curriculum reforms in science advocate a change from a didactic classroom to an inquiry classroom where changes in assessment are also necessary. In 2008, another review on education known as the Primary Education Review and Implementation (PERI) was carried out. During this review, there were specific recommendations that assessment practices shift from overemphasizing assessment of learning as an end outcome to viewing assessments as an integral part of a continuous process of learning. Assessments were adjusted to incorporate more thinking questions (Sellan, Chong \& Tay, 2006). Students were required to demonstrate their 
ability to apply their knowledge to circumstances or contexts that were new to them (Tan et al., 2014). This required higher-order thinking skills rather than just regurgitation of knowledge.

One of the most significant changes in assessment thinking in Singapore has been the greater emphasis and recognition given to formative assessment (Tan et al., 2003). When the inquiry approach was introduced, teachers in Singapore were increasingly encouraged to design assessment that enhances students' learning. As mentioned by Tan et al. (2003), there has been a pressing need for innovative and informed assessment practices to support innovative pedagogies such as TLLM. The approach towards the assessment of science practical skills saw a significant change in 2006 when the School-Based Science Practical Assessment (SPA) was introduced (Tan et al., 2014). The previous practical tests were criticized for not encouraging a sufficient number of thinking skills (Toh et al., 1991). The SPA focused on the assessment of students demonstrating their skills rather than simply making and recording observations. Students were now required to go beyond making and recording observations to planning investigations, selecting techniques, apparatus, and materials that suit the experimental requirements. This was in more alignment with the incorporation of inquiry skills during the ability-driven phase.

However, in its implementation, the SPA was inundated with challenges (Tan, Lim, \& Poon, 2014). Teachers found it difficult to play the role of both assessor and teacher to the students. Towndrow, Tan, Yung, and Cohen (2010) suggested that the teachers did not possess the adequate proficiency in assessment literacy to implement the SPA to its original intent. Due to the numerous problems, a review was conducted on the future of the SPA. As of 2017, it was eliminated as part of the national assessment.

Despite the end of the SPA, it is clear that its introduction was significant in aligning inquiry-based learning and thinking skills in the area of national science assessments. The SPA was an important advancement of the professionalism of the science teachers in Singapore (Tan, Lim, \& Poon, 2014). This episode on practical assessment reflected an essential reform that was required for national assessment to be in better alignment with the changing curricular objectives.

As mentioned in this section, there were significant impacts both directly and indirectly related to the initiatives introduced during the ability-driven phase. The Singapore government started increasing its resources in the area of biomedical sciences, environmental science, and interactive and digital media (Ng, 2010). In the next section, the impact on the science culture in Singapore is explored. 
Science culture refers to the attitudes of the public towards science and their general understanding of it (Solomon, 1996). A science culture begins and ends with people (Feuer et al., 2002), meaning that the science culture in a country is largely dependent on the behavior and attitudes of people towards science. These attitudes require systems and frameworks to be in place before they are formed. Various mechanisms exist for the dissemination of science knowledge to people in Singapore (Subramaniam, 2014). The role of schools in providing science literacy to students in Singapore is perhaps one of the major modes of dissemination. However, there are numerous other ways in which the public is influenced and informed about science, such as science and discovery centers, zoos, bird parks, and newspapers. Science culture can determine the public's way of living and thinking (Wang, 2018). Therefore, a strong science culture in a country would mean a scientifically literate society in which behavior and thinking are influenced by science knowledge.

A science culture was relatively non-existent in Singapore before the 1950s (Tan, Lim, \& Phua, 2017). There are three main reasons researchers have attributed to this absence of a science culture in Singapore. First, Singapore's immediate emphasis upon its founding in 1819 was on trade and commerce, and there was relatively little emphasis on science and technology. There was no necessity to incorporate science and technology into the education system nor a need to explore an additional avenue for socio-economic development during the colonial administration, as the nation's economy was thriving in trade (Tan, Lim, \& Phua, 2017). Second, the political instability in Singapore leading to independence contributed to the delay in the emphasis on the teaching of science and therefore a delay in the introduction of a science culture in Singapore. Singapore's governing bodies spent a significant amount of time on nation-building and the building of a cohesive multi-racial society through the educational policies implemented. Third, Singapore struggled to produce scientists of international repute who could drive the establishment of an educational institution focused on science during the pre-independence period (Tan, Lim, \& Phua, 2017).

The ability-driven phase focused on educational transformations that were essential in developing a knowledge-based economy and knowledge-based workers. The science culture that developed in the late 199os was a result of a series of initiatives and policies that laid the foundation for a strong science culture in Singapore today. Science culture developed through several policies such as compulsory education, TLLM, inquiry-based approaches in teaching, 
and the IT Masterplan. A key aspect of the science culture movement that was observed by Tan and Subramaniam (2009) was the inclusion of science education teachers in its movement. This was seen through the introduction of science societies that allowed teachers to network with scientists. This collaboration allowed non-scientists to appreciate the science knowledge from a discovery and experimental perspective rather than a delivery one. One such example is A*STAR, which was established in 2001 (Tan, Lim, \& Poon, 2014). The establishment of these societies represents an important shift in the nation's attitude towards science. Programs and competitions were introduced during the 1990s as well. In 1995, Singapore participated in TIMss, which involved 41 countries, and 14-year-old Singapore students ranked first in the Secondary Two science tests. The international average was 500, and Singapore scored 643, above South Korea, Japan, and Hong Kong. Goh and Gopinathan (2008) noted that the policy of streaming students according to their academic abilities allowed the teachers to focus on their teaching of science. This was meant to create publicity for science education.

The development of the science culture in Singapore allowed the nation to embrace life sciences in the 199os to allowed Singapore to develop a workforce that was competitive in the growing change in the international landscape. The ability of a small nation to stay competitive in a world with a constantly changing economic landscape can be attributed to a versatile and fluid education system.

\section{Discussion}

Initiatives during the ability-driven phase had an impact on the development of science education in Singapore. At the threshold of the 21st century, great strides were being made in the fields of computing technology, telecommunications, biotechnology, nanotechnology, and clean energy (Tan et al., 2014). Scientific developments were occurring at the boundaries of traditional science disciplines.

The first lesson to draw from this historical study is that through the introduction of TSLN, Singapore saw the beginnings of a reform in science education through the improvement of the interaction between teacher and students. It is important to note that the introduction of TSLN was an attempt to draw away from rote learning and to allow the students to be more adequately engaged in the learning process (Tharman, 2005). As highlighted by Ng (2007), the Singapore education system has been known for its strong academic rigor, direct teaching by the teachers, and repeated practice by the 
students. Therefore, even though Singapore has attained world-class standard in mathematics, computing, and other sciences, experts have pointed out the relative poor performance in the development of creativity and innovation in Singapore students (Tan et al., 2014).

The improvement of the interaction between teachers and students that was the intended outcome of TLLM allowed students to be more engaged in learning $(\mathrm{Ng}, 2007)$. At the end of the ability-driven phase, together with the support provided through teaching and learning platforms such as teacher training at NIE, there were improvements in the quality of science education (Tan, Lim, \& Poon, 2014), as seen by the TIMSS in 2011. Singapore had the highest proportion of students attaining the highest Advanced TIMss Benchmark for science. More recently, in 2015, Singapore scored the highest in the areas of science and mathematics on the PISA (Tan, 2018).

A second important lesson to be drawn is that the development of science education supported the emerging science research landscape in Singapore. The Singapore government embarked on an innovative economic strategy in research and development. The then Minister of State for Trade and Industry, S. Iswaran, commented that the government was committed to invest in research and development as a driver for economic growth and as a foundation for our long-term competitiveness (Iswaran, 2006). Tan et al. (2003) noted that this economic policy cannot stand alone. In a globalized and knowledgedriven world, education is seen as a prime source of economic competitive advantage (Porter, 1990).

Programs at the National Research Foundation were stepped up to encourage students to pursue careers in science and technology. During the abilitydriven phase, there were numerous opportunities for students with a passion in science to pursue it (Tan et al., 2014). In providing students with opportunities and platforms to explore their interest in science, Singapore was indirectly building its research and development capabilities.

Third, it is important to note that with any curriculum reform, sufficient support for teaching and learning is essential. The Ministry of Education in Singapore recognized three key areas of support or change required: teacher training, logistical, and assessment. Training was provided to support the teachers in implementing the inquiry approach through courses at NIE for both pre-service and in-service teachers. However, the enactment of science as inquiry has brought to the surface various difficulties and tensions (Tan, Talaue, \& Kim, 2014). Despite structured approaches to support the implementation of the inquiry approach, research in international communities of science education has shown that the implementation has been a daily struggle for science teachers (Crawford, 2007). The implementation of science as 
inquiry is challenging due to reasons such as students' attitudes towards the approach, teachers' competencies and belief systems, and lack of administrative support in the area of assessment implementation in alignment with the inquiry approach (Tan \& Tan, 2014). Therefore, further support in this area may be essential in furthering the inquiry approach.

Networking was also encouraged and curriculum study groups were started to support teachers in the implementation of new initiatives in the classroom. In addition, as mentioned, logistical support was also provided to schools in the form of funding and books. In addition, assessment was altered to accommodate to the change in teaching approaches.

The final historical lesson to gather from this paper is that the strength of an innovative, versatile education system is in its capacity to respond to the changes and growth in economical demands. In Singapore, education has consistently been the building block for economic and national development. Singapore's education academics, such as Gopinathan (1974) and Blackburn (2017), have labeled this as the education-economy nexus or relationship. According to Gopinathan (1974), the educational policies adopted in Singapore reflect an education-economy relationship. The aim of the implementation of these policies has been to build a skilled workforce in alignment with the demands of the economy. This was seen as necessary in Singapore due to its limited natural resources and its heavy reliance on its human workforce (Gopinathan, 1974). As the country has progressed, there has been a greater emphasis on science and technology in the curriculum. Through this, Singapore has been able to achieve "a tight coiling of education and training systems with state-determined economic policies" (Gopinathan, 2013, p. 40). This has contributed to Singapore's economic success despite its limited natural resources. Therefore, when Singapore reached an economic landscape demanding a knowledge-driven workforce, it was important that the education structure adapted accordingly.

The results from this study suggest that there may be value in further understanding the challenges and issues faced in the implementation of the inquiry approach in the classroom through focus-group discussions or interviews. One of the main objectives of the TLLM initiative was to allow students to be more adequately engaged in the learning process (Kadir \& Aksir, 2009). To support this, the inquiry approach was introduced in 2008 (Tan, 2015). The objective of the inquiry approach was to develop students as active learners (Tan, 
Talaue, \& Kim, 2014), therefore, growing their innovativeness and creativity. Unfortunately, as mentioned by Tan et al. (2014), experts have continued to point out the relatively poor performance in the development of creativity and innovation in Singapore students. In addition, teachers still struggle with the implementation of the inquiry approach (Tan \& Tan, 2014). This suggests that there may be misalignments in the intended outcome of the approach and its enacted outcome. This may be due to unforeseen challenges and issues faced in the classroom during the implementation of the inquiry approach. Further research on this may provide evidence on the exact support needed by the teachers and students in realizing the intended outcome of the inquiry approach.

The changing educational landscape of Singapore during the ability-driven phase from 1997 to 2011 is highlighted in this paper with the introduction of the TSLN vision in 1997. Through historical analysis, this paper has focused primarily on educational initiatives that were introduced in alignment with this vision. This paper focused specifically on two initiatives that had an impact on the development of science education in Singapore during the abilitydriven phase: TLLM and the IT Masterplan. The impacts of these policies on the development of science education in Singapore were discussed in this paper, focusing primarily on the impact on science education, training of science teachers, teaching and learning support, and assessment. Through this research, an insight into the rationale of the initiatives, the intended outcome of the initiatives, and the issues faced as a result is provided.

\section{Abbreviations}

ICT Information and Communication Technology

IT Information and Technology Masterplan

NIE National Institute of Education

OECD Organisation for Economic Co-operation and Development

PISA Programme for International Student Assessment

TIMSS Trends in International Mathematics and Science Study

TLLM Teach Less, Learn More

TSLN Thinking Schools, Learning Nation

SPA School-Based Science Practical Assessment 


\section{Acknowledgements}

I wish to express my gratitude to Emeritus Professor Keith Punch for his continued support as well as to the members of the National Library Board (Singapore) for their continued support and assistance.

\section{Ethical Considerations}

The data collected for this research did not involve human subjects so no human subjects approval was necessary.

\section{About the Author}

Vanessa Vinodhen is a science educator at the Ministry of Education in Singapore. She holds a Bachelor's Degree in Life Sciences from the National University of Singapore and a Master's Degree in Science Communication from Australia National University. She also holds a Doctoral Degree in Education from University of Western Australia. Her research focuses on understanding the development of science education in response to the changing economic climate in Singapore and internationally. She is also interested in curriculum innovations in the area of science and biology teaching and learning.

\section{References}

Boo, H. K. (2003). Primary science assessment in the context of thinking schools learning nation vision. Teaching and Learning, 24(2) 131-140.

Bybee, R. W., \& Fuchs, B. (2006). Preparing the 21st century workforce: A new reform in science and technology education. Journal of Research in Science Teaching, 43(4), 349-352. https://doi.org/10.1002/tea.20147.

Chang, S. C. A. (2001). Implementation of the "thinking schools, learning nation" initiative in Singapore. Journal of Southeast Asian Education, 2(1), 13-41.

Chen, A. Y., \& Koay, S. L. (2010). Transforming teaching, inspiring learning: 6o years of teacher education in Singapore, 1950-2010. National Institute of Education.

Coughlan, S. (2016, December 6). Singapore first place in school rankings. ввс News. https://www.bbc.com/news/education-38212070. 
Feuer, M. J., Towne, L., \& Shavelson, R. J. (2002). Scientific culture and educational research. Educational Researcher, 37(8), 4-14. https://doi.org/10.3102/0013189X 031008004.

Fraenkel, J. R., \& Wallen, N. E. (2010). How to design and evaluate research in education. McGraw-Hill Higher Education.

Goh, C. B., \& Gopinathan, S. (2008). The development of education in Singapore since 1965. In S. K. Lee, C. B. Goh, B. Fredriksen, \& J. P. Tan (Eds.), Toward a better future: Education and training for economic development in Singapore since 1965 (pp. 12-38). The World Bank.

Goh, K. S. (1978). Report on the Ministry of Education, 1978. Singapore Ministry of Education, Government Printer.

Gopinathan, S. (1974). Towards a national system of education in Singapore. 1945-1973. Oxford University Press.

Gopinathan, S.(2013).Education and the nation state: The selected works of S. Gopinathan. Routledge.

Gopinathan, S., \& Chong, S. (2008). Singapore. In T. O'Donoghue \& C. Whitehead (Ed.), Teacher education in the English speaking world: Past, Present, and Future (pp 121137). Information Age Publishing.

Gopinathan, S., Deng, Z., \& Lee, C. (2013). Globalization and the Singapore curriculum: From policy to classroom. Springer.

Gopinathan, S., Wong, B., \& Tang, N. (2008). The evolution of school leadership policy and practice in Singapore: Responses to changing socio-economic and political contexts (insurgents, implementers, innovators). Journal of Educational Administration and History, 40(3), 235-249. DoI: 10.1080/00220620802507250.

Iswaran, S. (2006, July 13). Speech at the UK-Singapore Conference for Building Science and Technology Capacity with South East Asian Partners. Singapore. https://www .nas.gov.sg/archivesonline/data/pdfdoc/2006o713981.htm.

Kadir, A., \& Akshir, M. (2009). Rethinking Thinking Schools, Learning Nation: Teachers' and students' perspectives of critical thinking in Singaporean education [Doctoral thesis, University of Melbourne]. University of Melbourne Library. http://minerva -access.unimelb.edu.au/handle/11343/35285.

Lange, M. (2013). Comparative-historical methods. SAGE.

Miles, M. B., Huberman, A. M., \& Saldaña, J. (2014). Qualitative data analysis: A methods sourcebook (3rd ed.). SAGE.

Ministry of Education, Singapore [MOE]. (n.d.). Education system. https://www.moe .gov.sg/education/education-system.

Mokhtar, I. A. (2005). Education in the information age-A preliminary study of the changing roles of school teachers in Singapore. Educational Research for Policy and Practice, 4(1), 27-45. https://doi.org/10.1007/s10671-005-3375-o. 
Mullis, I. V. S., Martin, M. O., Goh, S., \& Cotter, K. (Eds.) (2016). TIMSS 2015 Encyclopedia: Education Policy and Curriculum in Mathematics and Science. http://timssandpirls .bc.edu/timss2015/encyclopedia/.

$\mathrm{Ng}$, P. T. (2008). Educational reform in Singapore: From quantity to quality. Educational Research for Policy and Practice, 7(1), 5-15. https://doi.org/10.1007/s10671-007-9042-x. OECD. (2019). PISA 2018 results (Volume I): What students know and can do. https://doi .org/10.1787/5fo7c754-en.

Porter, M. E. (1990). The competitive advantage of nations. The Free Press.

Punch, K. (2014). Introduction to social research: Quantitative and qualitative approaches. SAGE.

Richardson, V., \& Placier, P. (2001). Teacher change. In V. Richardson (Ed.), Handbook of research on teaching (4th ed., pp. 905-947). American Educational Research Association.

Sellan, R., Chong, K., \& Tay, C. (2006, May). Assessment shifts in the Singapore education system. Paper presented at the $32 n d$ annual conference of International Association for Educational Assessment, Singapore.

Shanmugaratnam, T. (2005, September 22). Achieving quality: Bottom up initiative, top down support, focusing on quality and choice. Speech by the Minister for Education at the Ministry of Education Work Plan Seminar. https://www.nas.gov.sg/archives online/data/pdfdoc/20050922991.htm.

Solomon, J. (1996). School science and the future of scientific culture. Public Understanding of Science, 5(2), 157-165. https://doi.org/10.1088/og63-6625/5/2/005.

Tan, A.-L. (2015). Science as inquiry: Partnership for change in the 21st century. International Journal of Science Educators and Teachers, 1(1), 3-9. Retrieved from http://www.socialscienceasia.nrct.go.th/index.php/SSAsia/article/view/81/71.

Tan, A.-L. (2018). Journey of science teacher education in Singapore: Past, present and future. Asia-Pacific Science Education 4(1), 1-16. https://doi.org/10.1186/ s41029-017-0018-8.

Tan, J. (2012). Education in Singapore: Taking stock, looking forward. Pearson.

Tan, A.-L., Lim, S. S. L., \& Poon, C. L. (2014). Inquiry into the Singapore science classroom, Research and Practices. Springer.

Tan, B. T. G., Lim, H., \& Phua, K. K. (2017). 50 Years of Science in Singapore. World Scientific.

Tan, E. T. \& Ng, P. T. (2005). Shaping Singapore's future: Thinking schools, learning nation. Pearson/Prentice Hall.

Tan, G., Gopinathan, S., \& Ho, W.K. (2001). Challenges facing the Singapore education system today. Pearson Education Asia Pte Ltd.

Tan, K. C. D., Hedberg, J. G., Koh, T. S., \& Seah, W. C. (2006). Datalogging in Singapore schools: Supporting effective implementations. Research in Science \& Technological Education, 24(1) 111-127. https://doi.org/10.1080/02635140500485431. 
Tan, K. C. D., Teo, T. W., \& Poon, C.-L. (2016). Singapore science education. In M.-H. Chiu (Ed.), Science education research and practice in Asia: Challenges and opportunities (pp. 155-174). Springer.

Tan, L. W. H., \& Subramaniam, R. (2003). Science and technology centers as agents for promoting science culture in developing nations. International Journal of Technology Management, 25(5), 413. https://doi.org/10.1504/IJTM.2003.003110.

Tan P. H., \& Tan, A.-L. (2014) Teachers' ideas and concerns with assessment practices in inquiry science. In: A.-L. Tan, C. L. Poon, S. Lim (Ed.) Inquiry into the Singapore science classroom. Education innovation series. Springer.

Tan, W. H. L., \& Subramaniam, R. (2009). Role of scientific academies and scientific societies in promoting science and technology: Experiences from Singapore. International Journal of Technology Management, 46(1-2), 38-50. https://doi.org/ 10.1504/IJTM.2009.022674.

Tan, Y. K., Chow, H. K. \& Goh, C. (2008). Examinations in Singapore. Change and continuity (1891-2007). World Scientific Publishing.

Teh, L. W. (2014). Singapore's performance in PISA: Levelling up the long tail. In S. K. Lee, W. O. Lee, \& E. L. Low (Eds.), Educational policy innovations (pp. 71-83). Springer. https://doi.org/10.1007/978-981-456o-o8-5_5.

Teo, C. H. (2003, March 29). Address by RADM Teo Chee Hean, Minister for Education and second Minister for Defence, at the opening of the DNA Learning Lab at the Singapore Science Centre.

Toh, K. A., Diong, C. H., Chia, L. S., Boo, H. K., \& Yeo, T. K. (1991). A state-of-the-art review on science education in Singapore. Singapore Institute of Education.

Towndrow, P. A., Tan, A.-L., Yung, B. H. W., \& Cohen, L. (2010). Science teachers' professional development and changes in science practical assessment practices: What are the issues? Research in Science Education, 40(2), 117-132. DoI: 10.1007/ s11165-oo8-9103-z.

Wang, C. (2018). Scientific culture and the construction of a world leader in science and technology. Cultures of Science, 1(1), 1-13. https://doi.org/10.1177/20966o831800100102. 